\title{
Bureaucratically Missing: Capital Punishment, Exhumations, and the Afterlives of State Documents and Photographs
}

\author{
BIANCA VAN LAUN \\ Department of History, University of the Western Cape
}

For their families, the bodies of many of those hanged by the apartheid state remain missing and missed. Judicial executions, and the corpses they produced, were hidden from the scrutiny of the public and the press. While families might have known about the sentencing and fate of their relatives, and some might have come to Pretoria Central Prison to say goodbye and even attended a brief funeral service at the prison after the hanging, the state claimed and maintained control over the bodies of the condemned, both alive and dead. Families of the condemned were prohibited from viewing the bodies or attending burials, and while they could later request information about grave numbers, they were never allowed to recover the remains. ${ }^{1}$ Relatives could request that the remains be cremated but at their own cost, and even then, the ashes remained the property of the state and were not returned to the families. Many simply never knew what had become of their family members' remains.

Being prevented from seeing the body, taking the remains home, and attending or conducting a 'dignified burial' was a source of great sadness and distress for families. ${ }^{2}$ To add insult to injury, the bodies were buried in unmarked graves without ceremony or prayers. ${ }^{3}$ Relatives expressed disgust at the lack of care taken with the remains of hanged prisoners, lamenting the fact that their graves were 'no more than an empty space.' Indeed, some sections of Mamelodi Cemetery outside Pretoria, where hanged prisoners classified by the apartheid state as 'Bantu' were buried, still resemble desolate fields.

These missing dead who emerged from the state violence of judicial executions are now the focus of a government-run project that seeks to recover their remains, commemorate their political sacrifices and finally 'lay their ghosts to rest.' ${ }^{5}$ The Gallows

Many of the suggestions and thoughts in this article stem from conversations in the Forensic History Reading Group of the University of the Western Cape's History Department, and with my colleagues Nicky Rousseau and Riedwaan Moosage.

1 Madeleine Fullard, head of the South African National Prosecuting Authority's Missing Person's Task Team quoted in, eNCA, 'Bodies of hanged members of PAC's armed wing to be exhumed', 1 September 2017, https://www.enca.com/south-africa/bodiesof-hanged-members-of-pacs-armed-wing-to-be-exhumed (accessed 2 September 2017).

2 Mark Sanders has argued that, through witness testimonies given before South Africa's Truth and Reconciliation Commission, apartheid was revealed as having placed a 'proscription on mourning, specifically of the other'. M. Sanders, Ambiguities of Witnessing: Law and Literature in the Time of Truth Commissions (Standford: Stanford University Press, 2007), 35. See also M. van Bever Donker, R. Truscott, G. Minkley and P. Lalu, 'Traversing the Social', in M. van Bever Donker, R. Truscott, G. Minkley and P. Lalu (eds) Remains of the Social: Desiring the Postapartheid (South Africa: Wits University Press, 2017).

3 Black Sash, Inside South Africa's Death Factory (Johannesburg: Black Sash, 1989). Drawing on Garrey Dennie’s work, Nicky Rousseau has written of how pauper's graves were a source of great grief and loathing as they implied that particular 'bodies fell outside the boundaries of the sacred'. See N. Rousseau, 'Identification, Politics, Disciplines: Missing Persons and Colonial Skeletons in South Africa', in E. Anstett and J.-M. Dreyfus, Human Remains and Identification: Mass Violence, Genocide and the 'Forensic Turn', Manchester: Manchester University Press, 2015), 181. Dennie has written of the racialised treatment of dead bodies in South Africa and of how African families struggled to prevent their relatives from being buried as paupers. G. Dennie, 'The Standard of Dying: Race, Indigence and the Disposal of the Dead Body in Johannesburg, 1886-1960', African Studies, 68, 3, December 2009, 310-330; see also, P. Naidoo, Waiting to Die in Pretoria (Harare: Self-Published, 1990). 
Memorialisation Project, first announced in December 2011, involves the renovation and restoration of Pretoria Central Prison's death row as well as the gallows that were dismantled in 1996 after the death penalty was abolished in South Africa. The former death-row facility (located in what has since been officially renamed the Kgosi Mampuru II Correctional Facility) has been reimagined as the Gallows Memorial Museum, and it commemorates the 134 political prisoners who were hanged by the apartheid state between 1960 and 1989. ${ }^{6}$ The associated Gallows Exhumation Project, announced in 2016, involves the exhumation of the remains of political prisoners from unmarked graves in municipal cemeteries around Pretoria, and their reburial by their families and political organisations. Through the creation of a memorial museum, as well as the recovery and reburial of the remains, the Gallows Memorialisation Project emphasises the current government's stated goals of nation building, healing and the forging of a new, shared national identity.

The distinction between crimes as political or criminal is significant in the framing of the Gallows Memorialisation Project. A claim to the status of political prisoner (as opposed to ordinary criminal) enables particular individuals' remains to be exhumed and their lives to be commemorated. That is, the Gallows Memorialisation Project presents those who were hanged for their political activities as missing subjects in need of recovery and memorialisation but occludes those who were defined as criminal. That is, certain missed bodies have been accorded political afterlives as 'heroes of the nation.' For example, as part of the project, members of Poqo - the armed wing of the PAC - are being claimed as freedom fighters and political prisoners for their roles in what were mostly relatively small, localised skirmishes and uprisings that took place in the 1960s, some of which were unsupported by PAC leaders at the time. ${ }^{8}$ As Poqo suffered the loss of more of its members to the gallows than any other liberation organisation during apartheid, I foreground these cases.

The Gallows Memorialisation Project, however, is selective both about this history and the individuals to be commemorated, as well as about the ways in which commemoration is done. Under the project's auspices, bureaucratic documents and official identification photographs from the prison archives have been resurrected and reinterpreted. As theorist Allan Sekula put it, we are being embraced in a

6 Between 1960 and 1989 the death penalty was enforced for murders motivated by or related to political activities as well as acts of sabotage or treason. Fullard points out that more people were put to death during the 1960s for politically motivated crimes than in any other decade in South African history, noting that at least 101 men were hanged between 1960 and 1970, some 66 of whom were Poqo members. All of these executions resulted from just four years of resistance and political upheaval between 1960 and 1964 that, for the most part, can be linked to the activities of the Pan Africanist Congress (PAC) and its armed wing. During the same period, just seven members Umkhonto of We Sizwe (the African National Congress' armed wing) were hanged on charges of sabotage and murder. See M. Fullard, 'State Repression in the 1960s', in South African Democracy Education Trust, The Road to Democracy in South Africa: Volume 1, 1960-1970 (Pretoria: Zebra Press, 2004), 341-390, 382; M. Fullard, 'The Ultimate Penalty: Political Executions in the Period 1960 to 1994', unpublished manuscript.

7 C. Rassool, 'Human Remains, the Disciplines of the Dead, and the South African Memorial Complex', in D. Peterson, K. Gavua and C. Rassool (eds), The Politics of Heritage in South Africa: Economies, Histories and Infrastructures (New York: Cambridge University Press, 2015), 145.

8 Most Poqo members hanged by the apartheid state were tried in criminal cases and sentenced to death for murder, even though their actions were politically motivated. For some, the charges included sabotage. For more on this political/criminal binary, see B. van Laun, 'Administrative Death: Bureaucracy, Capital Punishment and Governmentality in South Africa During the 1960s' (PhD Dissertation, University of the Western Cape, 2018). See also, N Filippi, 'Deviance, Punishment and Logics of Subjectification During Apartheid: Insane, Political and Common-Law Prisoners in a South African Gaol', Journal of Southern African Studies, 37, 3, 2011, 627-643; and K. Gillespie, 'Against Reconciliation: The Politics of Crime' paper presented at the South African Contemporary History and Humanities Seminar, University of the Western Cape, 14 April 2015. 
practice of 'political maneuvering.' In this article, I examine ways in which prisoner files, documents and photographs, produced through the bureaucratic procedures that put prisoners to death on the gallows in the 1960s, have been reclaimed and repurposed by this post-apartheid nation-building and memorialisation project. ${ }^{10} \mathrm{I}$ show how the logic that sees to the reproduction of documents and photographs in the contexts of the Gallows Museum, and events organised by the Exhumation Project, while honouring the political hanged, is ultimately not dissimilar to the bureaucratic rationality followed by the apartheid state to fix identities and discipline particular individuals. That is, by replicating the bureaucratic rationality that produced prisoner photographs and documents, the person involved remains trapped in this logic and is still missing.

\section{The gallows as instrument of healing? Launching the Gallows Memorial Museum}

On 15 December 2011, then-president of South Africa Jacob Zuma officially unveiled the gallows and death-row facility at the Pretoria Central Prison as a national memorial museum. ${ }^{11}$ Cabinet ministers, leaders of political parties, human rights lawyers, and over two hundred relatives of political prisoners who were hanged in South Africa between 1960 and 1989, attended the two-day opening event. In a bid to help the families find closure, so the narrative went, former death-row warder Andre Steyn, guided relatives and others through the facility, following the route that their condemned relatives would have walked when they were led to the gallows. ${ }^{12}$ The previous day, relatives had been invited to a cleansing ceremony at a newly installed replica of the gallows. ${ }^{13}$ During this ceremony, the relatives and religious leaders offered prayers, burned imphepho (traditional incense) and laid flowers in remembrance. Thereafter, the relatives and other guests were taken to two of the Pretoria cemeteries where death-row prisoners had been buried to pay their respects. ${ }^{14}$

At its opening, the Gallows Museum was framed as a place where relatives of the hanged, former death-row warders, and South Africans more broadly, could confront and reflect on the violence of the past in ways that would supposedly help us to heal and move forward. The space was referred to as 'a place of healing' and 'a symbol of hope for the future. ${ }^{15}$ As part of the opening ceremonies, Zuma unveiled a dedicated

9 A. Sekula, 'Dismantling Modernism, Reinventing Documentary', Massachusetts Review, 19, 4, $1978,875$.

10 I use the term 'post-apartheid' to refer to the dispensation created by the first democratic government after 1994.

11 In April 2013, Zuma officially renamed the Pretoria Central Prison as the Kgosi Mampuru II Management Area. Kgosi Mampuru was hanged on 22 November 1883 at Pretoria Prison for his refusal to recognise the oppressive hut tax imposed on African households by the British colonial government during the 1860s.

12 A Mphaki, 'Gallows Museum honours the dead', The Star, 16 December, 2011, https://www.iol.co.za/the-star/gallows-museumhonours-the-dead-1199814 (accessed 12 February 2014).

13 The cleansing ceremony included practices used in bereavement rituals by communities in South Africa, for whom death is often considered a form of pollution to society as a whole, and who have purification and cleansing rituals to counteract this. In places of death, such as the gallows, cleansing rites are seen as necessary to purify the space; for example, incense made from imphepho (helichrysum) is burned to clear the air for the ancestors.

14 M Maharaj 'President Zuma to Honour Political Prisoners Executed at the Gallows', Politicsweb, 14 December 2011 , www. politicsweb.co.za/party/jacob-zuma-to-honour-134-hanged-political-prisoner (accessed 10 February 2014).

15 J. Zuma, 'Keynote Address on the Occasion of the Launch of the Gallows Museum at the Pretoria Central Correctional Center', 15 December 2011, http://www.anc.org.za/content/keynote-address-president-jacob-zuma-occasion-launch-gallows-museumpretoria-central (accessed 12 March 2014). 
wall embellished with individual plaques for the 134 political prisoners who had been executed at the prison, saying, 'today all 134 names are officially enshrined for eternity so that future generations will know what this country went through, so that we never go through a similar horror ever again.' Zuma went on to describe the museum as; 'a place where the political prisoners who were hanged there can be honoured and the past can be buried ... we therefore open this museum as a place of healing. We are opening this museum so that future generations can learn how things can go wrong if we lose our common humanness and shared nationhood, when we lose that sense of respecting each other as human beings. ${ }^{16}$ Then-Minister of Correctional Services, Nosiviwe Mapisa-Nqakula, noted that, for her, there was no question that the gallows needed to be reconstructed; she described the 1996 dismantling of the gallows as 'an attempt to rob the people of South Africa of an opportunity to understand the painful history of executions. ${ }^{17}$

As noted, the Gallows Museum focuses on the individuals who were hanged by the apartheid state between 1960 and 1989 on charges related to politically-motivated offences. ${ }^{18}$ Thousands of others who were hanged on charges categorised as criminal have been excluded. A roll of honour on two huge granite slabs located outside the Museum lists the names of everyone executed in South Africa between 1912 and 1989 - some 4003 names (see Figure 9).${ }^{19}$ However, on this list, political prisoners are distinguished from common-law criminals, with the names of the political prisoners shown in bold white lettering. Political executions are made to stand out as the focus of the museum.

While the site of the gallows and the death-row block has the potential to represent and comment on a wider history of capital punishment in South Africa, the exhibit says almost nothing about ordinary criminals who were executed at this prison. The structural violence of apartheid that landed many young black men on death row does not fit the narrative of political prisoners killed by the state for their part in the struggle for freedom. The museum seems to have created a 'hierarchy of victimhood' in which 'political prisoners have been deemed to matter more than common-law prisoners. ${ }^{20}$ That is, the specific political agenda that seeks to memorialise only political prisoners compromises the museum's purported efforts to confront and learn from the history of judicial executions, and to contribute to a more democratic and inclusive culture in South Africa. ${ }^{21}$

\footnotetext{
Zuma 'Keynote Address', Associated Press, 'South Africa's gallows now instrument of healing', 1 March 2012.

Quoted in Mphaki, 'Gallows Museum'.

Zuma, 'Keynote Address'; Maharaj, 'President Zuma'.

9 Most hangings in apartheid South Africa took place at Pretoria Central Prison. However, the so-called independent homelands or bantustans of Transkei, Ciskei, Venda, and Bophuthatswana each had their own gallows where hangings took place when death sentences were imposed. M. Fullard, 'The Ultimate Penalty: Political Executions in the Period 1960 to 1994', unpublished paper, 7; M. Fullard, Unpublished Manuscript, 150; S. Duncan, 'On Hanging,' Records of the Black Sash, AE 862, D36.2.15, Historical Papers Research Archive, University of Witwatersrand.

20 S. Karl, 'Rehumanizing the Disappeared: Spaces of Memory in Mexico and the Liminality of Transitional Justice', American Quarterly, 66, 3, 2014, 727-748: 742.

21 Amy Sodaro argues that memorial museums are always political tools, and are often used to further specific political agendas that can compromise the work of producing a more inclusive and democratic culture. See A. Sodaro, Exhibiting Atrocity: Memorial Museums and the Politics of Past Violence (London: Rutgers University Press, 2018), 5.
} 
The Gallows Museum was expected to open in 2012, with its own entrance and exit, separate from the still-operational high-security prison. ${ }^{22}$ However, at the time of writing seven years later, security concerns keep the museum closed to the general public unless special arrangements are made.

\section{'Resurrecting' the archives: documents, photographs and memorialisation}

According to philosopher Paul Williams, effective memorial museums depend on three things - objects, image and space. At the Gallows Museum, many of the objects on display are mundane - a chair, a table, a cupboard, a telephone - but the context they come from, and their proximity to the replica of the actual gallows, loads them with affective and historic weight. In addition, the museum curators have captured a narrative of the procedures involved in carrying out executions partly through a display of bureaucratic documents. From the warrant of execution delivered by the sheriff of the court to the notice of death and prisoner's autopsy report, a paper trail, some of which is on display, attests to the routinised and bureaucratic administration of every aspect of each execution. Indeed, the display of these documents and prisoners' identification photographs clearly conveys the violence and brutality of this state-sanctioned killing system. The documents and photographs seem to stand for the administrative power of the state, and convey something of the mind and functioning of apartheid itself. At the same time, the documents reference once-living individuals and thus offer something of a biography.

Through a series of bureaucratic engagements and documentation that measured, classified, described and defined the individual, the apartheid state produced each prisoner as a case - an object, an effect and a target of power. The prison files of hanged prisoners contain a myriad of documents - police identification forms, police dockets, prison-transfer forms, letters, telegraphs, requests for leave to appeal and so much more. Through their classifications and categories, the taking and collecting of prisoner statements and profiles, these documents produced and rewrote individual prisoners in ways beyond their control. Included here are recordings of the body measurements, including height, weight, and neck size, that made a 'successful hanging' possible. The documents reflect the kinds of disciplinary power that Michel Foucault invokes - a power that demands that subjects be examined so that they can be made visible and knowable. Central to the examination of prisoners' bodies was the process of recording. That is, the power of inscription 'captured and fixed' the identities and attributes of individuals within a 'network of writing' that placed them in a permanent analytic space. ${ }^{23}$

As museum exhibits, these archival documents have been given new life. 'Resurrected' from the prison archives, they are intended to tell the story of the ways in which the apartheid state carried out judicial executions. In this setting, the documents have been partially transformed from instruments of repression and

\footnotetext{
K. Ritchie, 'Inside SA's Factory of Death', Saturday Star, 12 December 2011.

M. Foucault, Discipline and Punish: The Birth of the Prison (New York: Vintage, 1995), 189.
} 
control into a means of post-apartheid reckoning. ${ }^{24}$ In her work on police archives in Guatemala, historian Kirsten Weld questions whether such archives can 'offer a new chance at postwar reckoning. ${ }^{25}$ Weld describes the discovery of a collection of around 80 million pages of once-secret police documents, as well as their restoration, organisation and rehousing in the newly created Archivo Historico de la Policia Nacional (Historical Archives of the National Police). When uncovered, the documents were beginning to decay, and Weld describes them as "paper cadavers" in need of restoration.'26 She explains how a small group of human-rights activists have subsequently used the files produced by former perpetrators as 'part of an unprecedented effort to rewrite history', invoking a conversation about historical memory and transitional justice. ${ }^{27}$

Weld then outlines how the documents were reimagined in Guatemala's post-war context. She points out that the documents represent two different archival logics that held sway at different times. The first logic produced the documents. Driven by ideas of surveillance and of ideological and social regulation, the documents were used as a weapon against those considered enemies of the state. The second logic arose out of the recovery of the documents in a context of 'democratic opening, historical memory and the pursuit of justice for war crimes. ${ }^{28}$ The second logic also utilises the archives as a weapon but for a very different purpose. Weld is interested in how the first logic evolves into the second, and how this reflects Guatemala's transition from a state of civil war into a volatile peace. ${ }^{29}$

Weld's work is useful to think with, as the prison files, documents and photographs produced as part of a logic of surveillance and control by the apartheid state are 'resurrected' from prison archives and reimagined in the post-apartheid setting. In the Gallows Museum, state documents and photographs have been recovered with the aim of restoring personhood, honouring the men executed, and representing the history of one aspect of apartheid-era judicial executions. Accordingly, the documents and photographs have been re-presented by the Gallows Memorialisation Project as part of the logic of nation-building, political commemoration and 'healing. However, in this case the two logics are not as separate as Weld suggests. The bureaucratic rationality that produced the original documents is not entirely different from that which has since seen a specific subset of documents reproduced in the context of the Gallows Memorialisation Project. In some senses, the current project continues to do the work of fixing the identity of particular individuals, while enacting current political priorities.

In the Gallows Museum, the white-tiled walls of what was once the autopsy room now display enlarged copies of official prison documents. Included here are prisoners' official death notices, autopsy reports, and copies of police identification forms

Weld, Paper Cadavers, 44. 

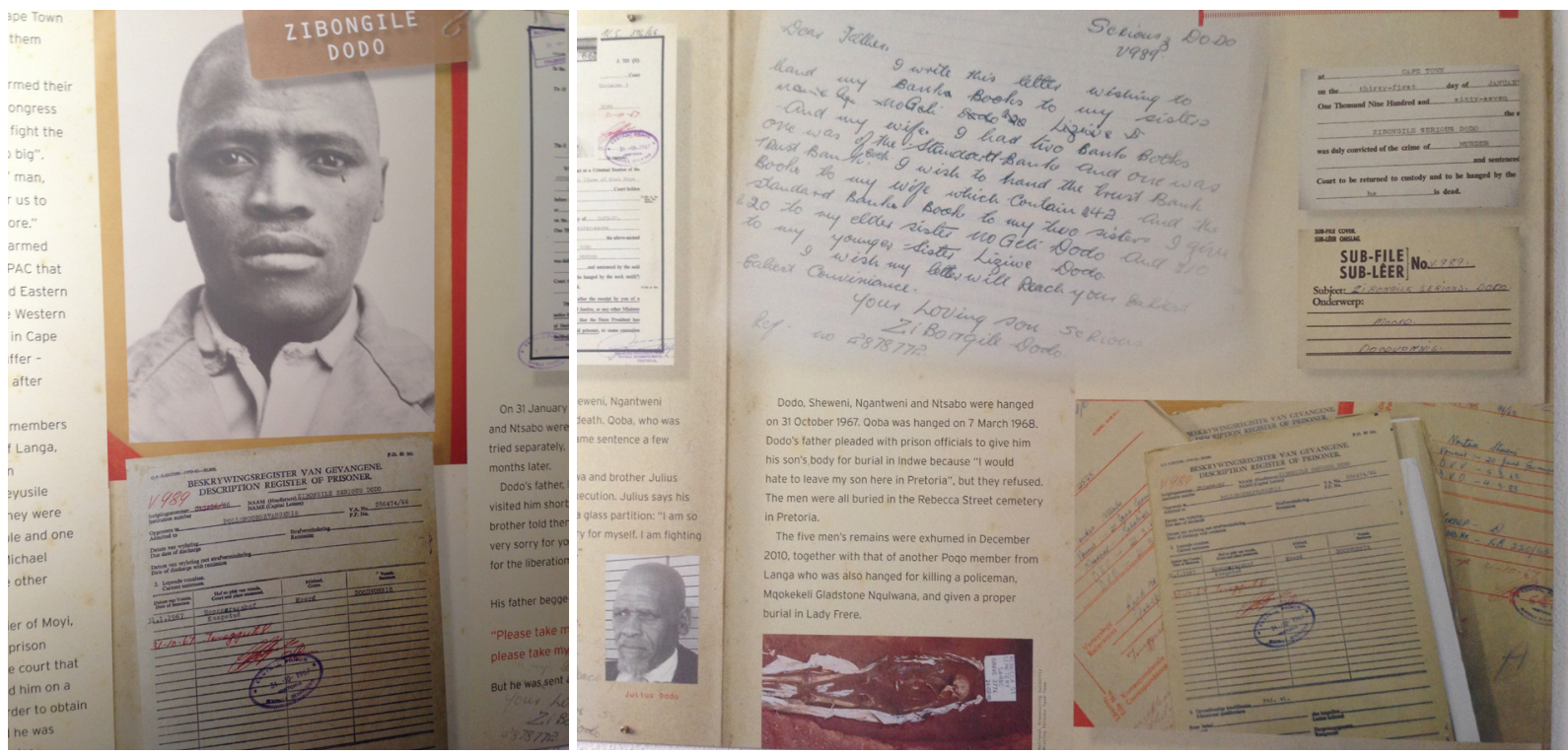

Figure 2: (above left) The information board on Zibongile Dodo features a copy of his official description, Gallows Memorial Museum, August 2017. Photograph by Bianca van Laun.

Figure 3: (above right) Various documents included in the information board on Zibongile Dodo, Gallows Memorial Museum, August, 2017. Photograph by: Bianca van Laun.

At no point on the families' specially arranged tours through the museum are these documents discussed and there is no concerted effort to encourage them to engage with the documents or consider the nature of a regime that facilitated the systematic execution of certain citizens, or reflect on what kind of state needs to collect and store the kind of knowledge that is contained in this archive. There is no discussion of how these documents were constitutive of bureaucratic actions and processes that accompanied and facilitated capital punishment. In some ways this is expected to be self-evident. Few of the visitors who pass through the autopsy room stop to read the documents. The focus for the relatives, who are museum's only visitors for now, is largely directed towards the moment of hanging, and seeing their dead commemorated in the museum's photographic exhibition as well as on the individual plaques inscribed with their names in the gallows room. The emphasis is on the cruelty of apartheid and the sacrifices of the hanged, rather than on how deeply the judicial executions carried out here were enmeshed within a larger apparatus that may help us to better understand the bureaucratic nature of the apartheid state.

At various points in the museum are information boards that provide brief biographic narratives of selected individuals. ${ }^{30}$ These include fragments of documents

30 The biographies of four individuals hanged by the apartheid state are included in the museum. These are Vuyisile Mini, Frederick John Harris, Zibongile Dodo and Solomon Mahlangu. As mentioned, the cases of both Mini and Mahlangu (both members of MK) received significant publicity and appeals for their lives to be spared came from around the world. As liberation struggle icons, both men have already been commemorated through monuments and in museums elsewhere. John Harris, a member of the Liberal Party's African Resistance Movement (ARM), is included as the only white person to be executed for politically motivated crimes against apartheid. Of the four, Zibongile Dodo, who was hanged in 1968, is the only PAC/Poqo member. 


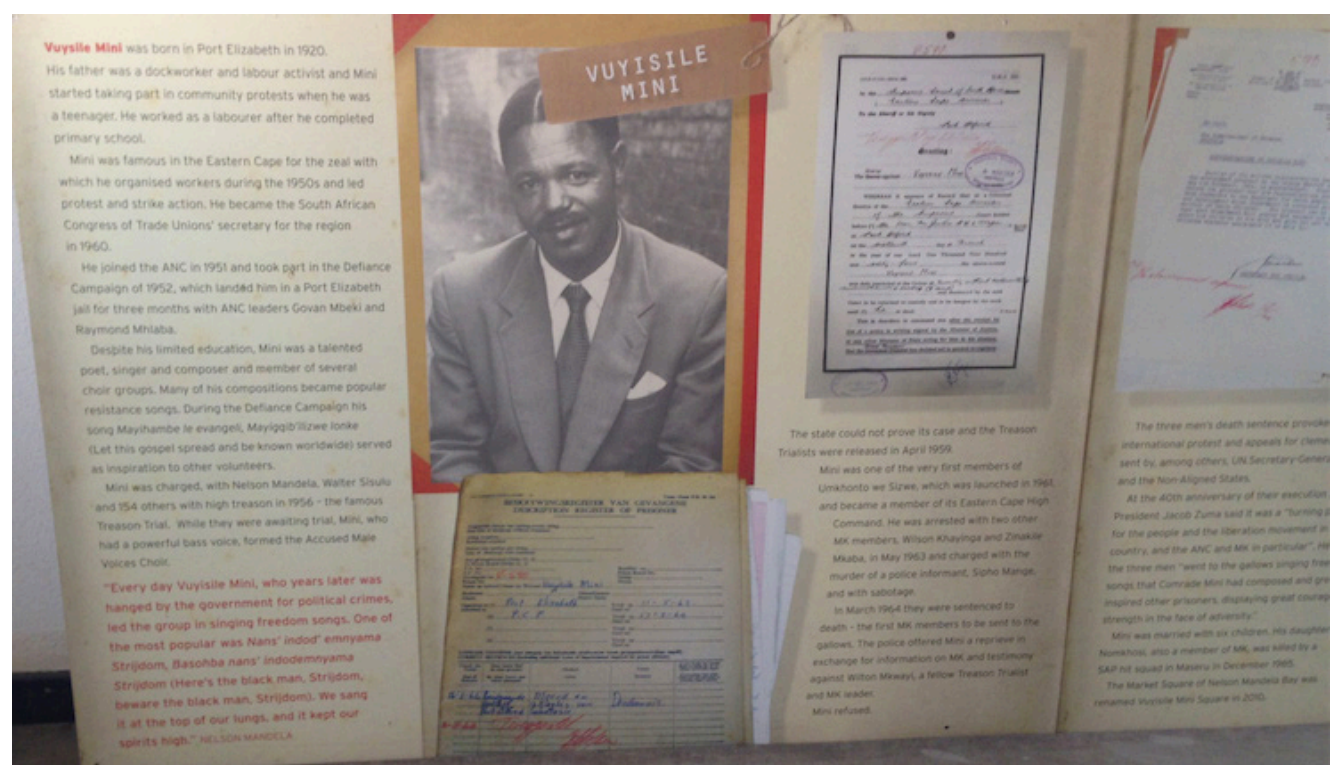

Figure 4: Information board on Vuyisile Mini, Gallows Memorial Museum, June 2015. Photograph by Bianca van Laun.

taken from prison files, such as letters, warrants of execution, and the cover of one prisoner's file with the Afrikaans word for executed (Tereggestel) inscribed across it in red ink. Often the biographical narrative provided within these texts does not refer to the documents included. The documents on the information boards appear to be merely illustrative and seem to have been provided as part of the biographic detail of the lives of particular political prisoners. In other words, the prison documents are included as evidence of what happened but with no discussion of the history of their production or of what Arjun Appadurai called the 'social lives' of the documents. ${ }^{31}$ Thus, while they represent the bureaucratic administration of life and death by the apartheid state, the systems and institutional networks that they reference are not explained or critiqued in any way. While such bureaucratic documents hold the potential to reveal much about the mind of the apartheid state and its workings, in this rendering they do little more than portray the evil of the apartheid state.

Ultimately, the official documents say little about the lives of the people they reference. The documents are symbolic only of a life within a larger tragic historical narrative. What the relatives of the hanged find in the displays is not evidence of a unique and irreplaceable individual, but rather an abstract entity as documented by

31 Drawing on the work of Appadurai and others, I argue that the bureaucratic documents produced and relied upon by the apartheid state in the practice of capital punishment can be thought of as having had 'social lives' and 'careers', the tracking of which might provide insight into the bureaucratic mind of the state. See Van Laun, 'Administrative Death', 115-172; A. Appadurai, 'Introduction: Commodities and the Politics of Value', in A. Appadurai (ed.), The Social Life of Things: Commodities in Cultural Perspective (Cambridge: Cambridge University Press, 1986), 3-63; M. Hull, 'Documents and Bureaucracy', Annual Review of Anthropology, 41, 2012, 251-267. 
state bureaucrats. As Weld argues, resurrecting 'paper cadavers' ultimately provides us with only 'a testament to the repression suffered ... a thin and tragic representation of a once-full life. ${ }^{32}$ It seems to me that the problem lies in the failure of the museum's designers to see that the logic of the document's production constrains the logic of its reinterpretation. As a result, the documents can never provide a basis for recovering the biographical subject, as the files and the archives in which they remain continue to be sites of power and subjectification rather than of retrieval and reclaiming.

Alongside objects and text, photographs play a key part in the production of meaning in the Gallows Museum exhibits. Photographs produced and used by the police and prison authorities to identify prisoners at various moments in the lead up to their execution, have been reproduced repeatedly in the museum. Most striking is the display of 134 block-mounted identification photographs in a single room (see Figure 5). The images are principally administrative, following a mode in which prisoners' physiognomic features had to be clearly visible. When these head-andshoulders mugshot-style portraits were taken, prisoners were placed in front of a white wall, with a black line indicating exactly where the centre of the head was to be positioned (see Figure 6). However, after being re-claimed from the state archive, and before being placed in the museum, the images were changed. The black line visible behind each prisoner in the original photographs has been edited out. Similarly, the prisoner and fingerprint numbers included above each prisoner in the originals have also been removed. Rather than a prison number, each photograph is now accompanied by a label that provides the individual's name.

In an effort to move away from their original intention of identification, surveillance and subjectification, the photographs in this rendition are intended to take on an honorific role..$^{33}$ In the context of the museum, the photographs are intended to act as a visual reminder of the humanity of those pictured - each face representing a life. Curator, Anneliese Burgess suggests that, 'a key challenge for us was to humanise the political prisoners again, and the best way we could think of was to give them back their names and their faces.. ${ }^{34}$ These men had indeed been stripped of their humanity by the apartheid state, and produced as irredeemably 'savage' to justify their execution supposedly for the sake of security. As Foucault argues, racism allows a state to deploy violence without undermining its biopolitical role of maintaining life. ${ }^{35}$ In an effort to reverse this, the museum endeavours to rehumanise the political hanged.$^{36}$ At the same time, by displaying them together, as Burgess suggests, the photographs are also meant to portray a collective who were targeted for political reasons. ${ }^{37}$ Ultimately, the photographs are a reminder that the individuals pictured

32 Weld, Paper Cadavers, 67.

33 For a discussion of the honorific and repressive functions of photography, see A. Sekula, 'The Body and the Archive', October, 39 , 1986, 3-64.

34 Email correspondence with Anneliese Burgess, 7 February 2018. Burgess has been part of the memorialisation project since its inception. Prior to this, she was part of a team of investigative journalists who compiled the weekly reports for the 87-part television series, Truth Commission Special Report, which was aired by the South African Broadcasting Corporation (SABC) every week between 21 April 1996 and 29 March 1998.

35 M. Foucault, Society Must Be Defended: Lectures at the College De France, 1975-76 (New York: Picador, 1997), 254-256. See Van Laun, 'Administrative Death', 99, 105

36 See Sylvia Karl's definition of rehumanisation in 'Rehumanizing the Disappeared', 727-748

37 This can be thought of in terms of what Cory Kratz refers to as the 'massing technique' in her article in this issue. 


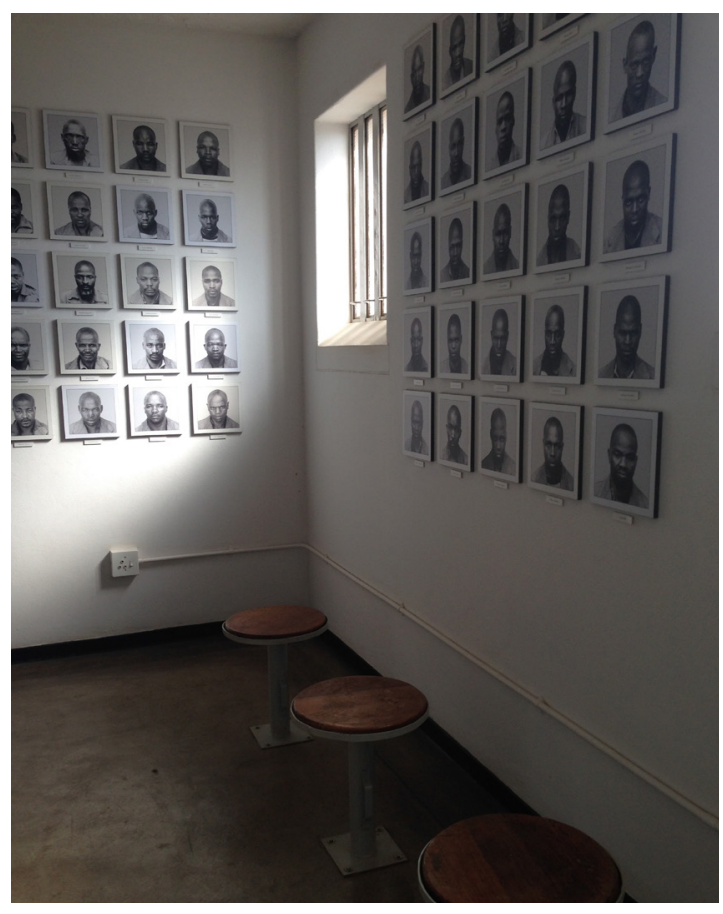

Figure 5: A section of the room in which portraits of 134 political prisoners are displayed, Gallows Memorial Museum, June 2015. Photograph by Bianca van Laun.

continue to be absent and missed. As Jenny Edkins puts it, 'Photographs make the missing visible. But photographs themselves are ambiguous, at once present as objects yet inevitably records of an absence. ${ }^{38}$

Several small stools placed in the photograph room encourage visitors to sit and reflect on the photographs, to really 'see' each face. Yet, the large number of faces quickly overwhelms the visitor, allowing us no space to consider that what we 'see' in these photographs is what the state/police/prison wanted to 'see.' Indeed, aside from the deliberate erasure of the line behind the prisoner and the prison and fingerprint numbers, the function of these photographs in the Gallows Museum in some ways replicates the processes of identification that first produced them. That is, their display in this context is also part of a process of verification and identification that allows for particular individuals to be memorialised to the exclusion of others. Driven by its memorialising and honorific agenda, little attention is given to how the photographs might further a deeper understanding of the administrative violence of capital punishment. ${ }^{39}$ In this rendition, attention to their original use has been obscured. The context of their production, what this might tell us about the bureaucratic and administrative systems that produced them, and the material practice of photography within an apartheid prison setting, are not mentioned or reflected on anywhere in the exhibit.

38 J. Edkins, Missing: Persons and Politics (London: Cornell University Press, 2011), 1.

39 In a study on the photographs of the Tuol Sleng Security Center in Cambodia, James Tyner and Christabel Devadoss draw on Walter Benjamin's conception of administrative violence as both 'law-making' and 'law-preserving'; J. Tyner and C. Devadoss, 'Administrative Violence, Prison Geographies and the Photographs of Tuol Sleng Security Center, Cambodia', Area, 46, 4, 2014, $361-368$. 

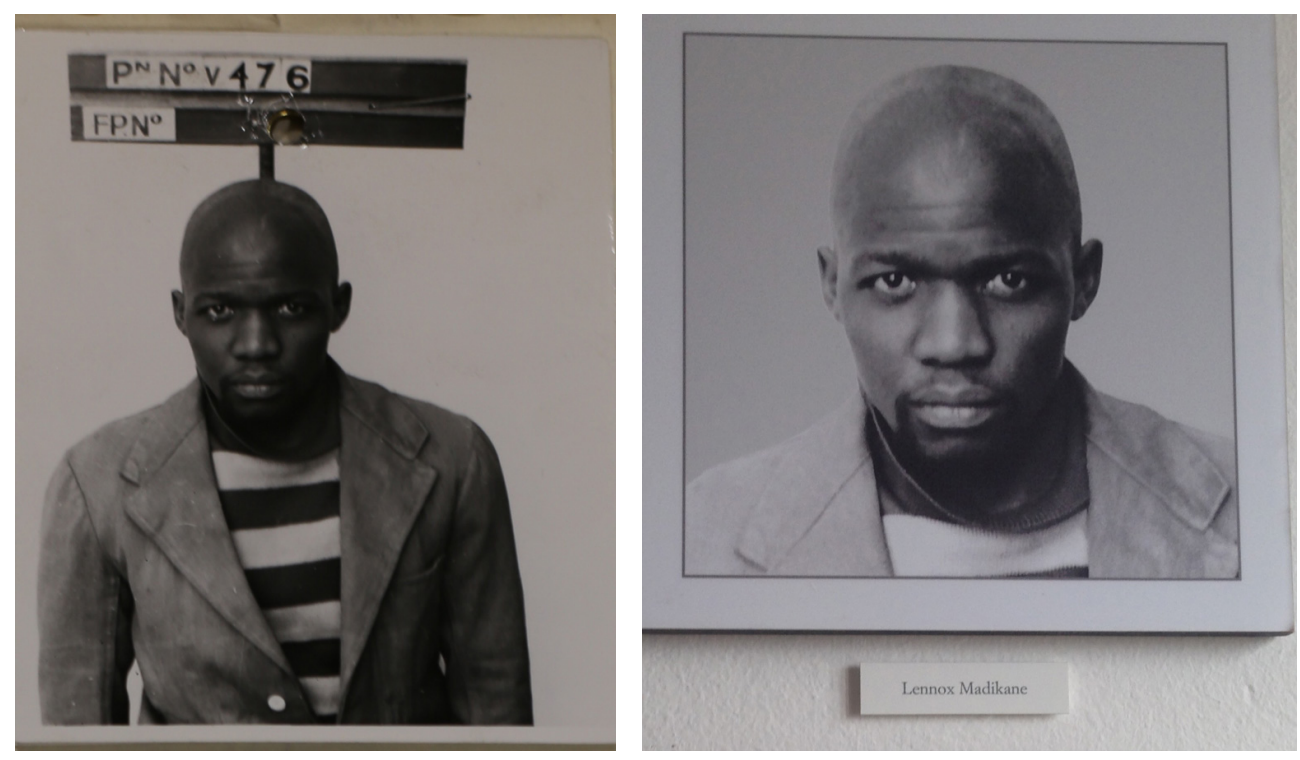

Figure 6: (left) Photograph of Lennnox Madikane from the official prison archive bearing his prisoner and fingerprint numbers.

Figure 7: (right) Photograph of Lennox Madikane, Gallows Memorial Museum, June 2015. Photographs by Bianca van Laun.

In a gesture of return, healing and commemoration, relatives of the 134 political prisoners were presented with their own framed copy of these portraits during the Gallows Museum's opening event. These, according to The Star, 'brought joy to some as they had never seen their loved ones either because they were babies at the time or the families had never had their photos. ${ }^{40}$ Taken up in a new relationship with the living, these images can now be read very differently. Historian Patricia Hayes has illustrated how photographs that were once part of identity documents - a repressive apparatus devised to control the movements and lives of black South Africans - can and have been copied, enlarged and framed by families, particularly in cases where no other photograph of the individual existed. These, once repressive, images have been reclaimed and reimagined, becoming cherished family possessions. Referring to such images, Hayes draws on Sekula to suggest that,

Some 'portraits' have a kind of double effect: many viewers today find them honorific, and then realise they were repressive. But they can flicker back as well, as the personal force or dignity shines through the prison or anthropometric backdrop. ${ }^{41}$

Indeed, while the walls of photographs displayed in the museum are uniformly arranged, it is through this uniformity that the 'person force or dignity' and other affective dispositions, become evident. 


\section{The Gallows Exhumation Project}

On 23 March 2016, South Africa's justice minister, Michael Masutha, officially launched the next phase of the Gallows Memorialisation Project. ${ }^{42}$ This involves the exhumation and reburial of 83 political prisoners who were hanged at Pretoria Central. ${ }^{43}$ Several delays followed the launch but, in December 2016, the exhumations began. ${ }^{44}$ The exhumations are intended to be a further step towards providing a form of closure for families of the hanged ${ }^{45}$ In addressing guests at the launch of the Exhumation Project, Masutha emphasised the importance of recovering the remains of these 'gallant fighters' and of handing them over to their families for 'dignified reburials. ${ }^{46}$ Both families and the media seemed to emphasise the notion that a 'decent funeral' and 'proper burial' would finally enable some closure and peace. ${ }^{47}$

Research and exhumations have been conducted by the Missing Persons Task Team (MPTT) together with the Truth and Reconciliation Commission (TRC) Unit in the Department of Justice and Constitutional Development. ${ }^{48}$ The MPTT has its origins in the TRC. The Promotion of National Unity and Reconciliation Act (1995) provided the TRC with the mandate to make recommendations to the State President. Among these recommendations was the proposal for the establishment of a team that would investigate cases of missing persons as reported to the TRC. As a result, in 2004, the National Prosecuting Authority established the MPTT within its Priority Crimes Litigation Unit. The MPTT was tasked with investigating the cases of persons who disappeared between 1 March 1960 and 10 May $1994 .{ }^{49}$ When the Gallows Memorialisation Project was set up, it fell to the MPTT to locate, exhume and identify the remains of hanged political prisoners, and to the TRC Unit to return the remains to their families.

42 M. Rahlaga, 'Gallows Exhumation Project to Launch Today', Eyewitness News, 23 March 2016, http://m.ewn.co.za/2016/03/23/83political-activists-hanged-in-the-gallows-will-be-exhumed-today (accessed 5 April 2016). M. Rahlaga, 'Masutha Launches Gallows Exhumation Project', Eyewitness News, 23 March 2016, http://ewn.co.za/2016/03/23/Masutha-launches-gallowsexhumation-project; Department of Justice and Constitutional Development, Exhumation of 83 Political Prisoners to Commence on 04 April 2016', 23 March 2016, http://www.justice.gov.za/m_statements/2016/20160323-GEproject.html_(both accessed 5 April 2016).

43 By this time, the remains of 47 political activists executed in the 1960s had been exhumed by the MPTT and some had been exhumed by their families. Independent Online, 'Langa Six Remains Exhumed', 25 February 2010, www.iol.co.za/news/politics/ langa-six-remains-exhumed-474565; News 24, 'Activists' Remains to be Exhumed', 23 February 2010, www.news24.com/.../ news/activists-remains-to-be-exhumed-20100223 (both accessed 10 October 2014).

44 These were the 12 Mbashe PAC members. See B. Maaba, 'The PAC's War Against the State, 1960-1963', in South African Democracy Education Trust, The Road to Democracy in South Africa: Volume 1, 1960-1970 (Pretoria: Zebra Press, 2004), 282. See also Die Burger, 'Transkei-Gruwel: Polisie op Spoor', 6 February 1963. According to Fullard, the Eastern Cape Provincial Government had requested that the MPTT start with these cases as the majority of hanged individuals were Eastern Cape cases. The process was delayed by several logistical processes including the transporting of families to Pretoria and finances (Email correspondence with M. Fullard, 19 February 2018).

45 Rahlaga 'Gallows Exhumation Project to Launch Today'; eNCA, 'Gallows Exhumation Project to Bring Closure to Families of Executed Political Prisoners', 23 March 2016, https://www.enca.com/media/video/gallows-exhumation-project-bring-closurefamilies-executed-political-prisoners?playlist $=107$ (accessed 5 April 2016).

46 M. Mautha, 'Address by Minister of Justice and Correctional Services at the Launch of the Gallows Exhumation Project at Kgosi Mampuru II on 23 March 2016' http://www.justice.gov.za/m_speeches/2016/20160323_GallowsExhumationProject.html (accessed 5 April 2016).

47 Times Live, 'Hanged Struggle Heroes' Remains Hailed', Times Live, 7 November 2017, https://www.timeslive.co.za/politics/201711-07-hanged-struggle-heroes-remains-hailed (accessed 10 November 2017).

48 At the time of writing, some of the remains were still being formally handed back to families and reburied. As of 19 February 2018, around 45 sets of remains were still to be exhumed (email correspondence with Madeleine Fullard, 19 February 2018).

49 See the TRC's definition of missing persons. Report of the Truth and Reconciliation Commission: Volume 6 (Cape Town: Juta, 2003), 512-549. 
The MPTT's preliminary work is historical and investigative. Its staff spend much time trawling through various archives, focusing on police and prison documents, trial transcripts, mortuary books and cemetery records. ${ }^{50}$ Forensic work commences once a potential gravesite has been identified..$^{51}$ The team uses professional surveyors to map the graves, cemetery records to confirm grave numbers provided in prison documents, as well as various archaeological practices. Beyond the locating and exhuming of remains, the MPTT works to uncover and reveal 'the story' of what happened to the individuals concerned. Developing an understanding of the circumstances surrounding an individual's death - and the procedures followed on death row - involves archival research and a tracking of the bureaucracy that surrounds any death.

When exhumations are carried out, the TRC Unit arranges for relatives of those being exhumed to be brought to Pretoria, taken on a tour of the Gallows Museum, and given a detailed description of death row and the hanging. ${ }^{52}$ However, understanding the bureaucratic process seems far less important to the families than experiencing the moment of their relative's death and reclaiming their remains. In the museum, family members actively engage with the copies of prison documents, photographs and the names represented. They fill the photograph room, each taking a turn to get up close and point to their relative's photograph. They whip out their cell phones and take photographs of the photograph or ask someone to take a photograph of the family with the image in the background almost as if reinserting the hanged relative into a family portrait.

After the tour, family members are often also taken to Freedom Park, ${ }^{53}$ where they are shown the names of their hanged relatives inscribed on the Wall of Names. Here the names feature among the names of thousands of others who lost their lives in numerous conflicts in South Africa's history - a reminder that the Gallows Museum, and their visit, is part of a larger nation-building project. They are then bused to the municipal cemetery where the MPTT has worked to expose the remains for the families' to view. Crowding around the open graves, this is when families see the remains, and are able to carry out the rituals denied to them at the time of death.

In contrast with the secrecy of the burials, the exhumations are a public affair. Not only do families witness the exhumations but members of the media are officially invited by the Department of Justice to witness and record them. While the prisons strictly enforced the rule that 'no photos may be taken' at the time of executions, the

50 According to Fullard, cemetery records are used to confirm the grave numbers of individuals to be exhumed, as well as physical information about the individuals buried beside them to aid the MPTT in making accurate identifications. The MPTT also produces a brief history of each case for the justice minister, the National Prosecuting Authority, and the media, by consulting trial records and newspaper articles at the Johannesburg City Library (email correspondence with Madeleine Fullard, 19 February 2018). Also see Fullard, this issue.

51 See E. Weizman, 'Introduction: Forensis', in E. Weizman, Forensic Architecture: Notes from Fields and Forums (Ostfildern: Hatje Cantz Verlag, 2012). E. Weizman and T. Keenan, Mengele's Skull: The Advent of Forensic Aesthetics (Berlin: Sternberg Press, 2012).

52 SA News, 'Families Visit Gallows to Mourn Loved Ones', 16 December 2011; City Press, http://allafrica.com/stories/201112161231. html (accessed 10 July 2014); News 24, '52 Steps to death', 13 August 2017, https://www.news24.com/SouthAfrica/News/52steps-to-death-20170812 (accessed 13 August 2017).

53 Freedom Park is a memorial park in Pretoria that includes walls bearing the names of people who were killed in the South African Wars, World War I and II, as well as those killed in the struggle to end apartheid. 

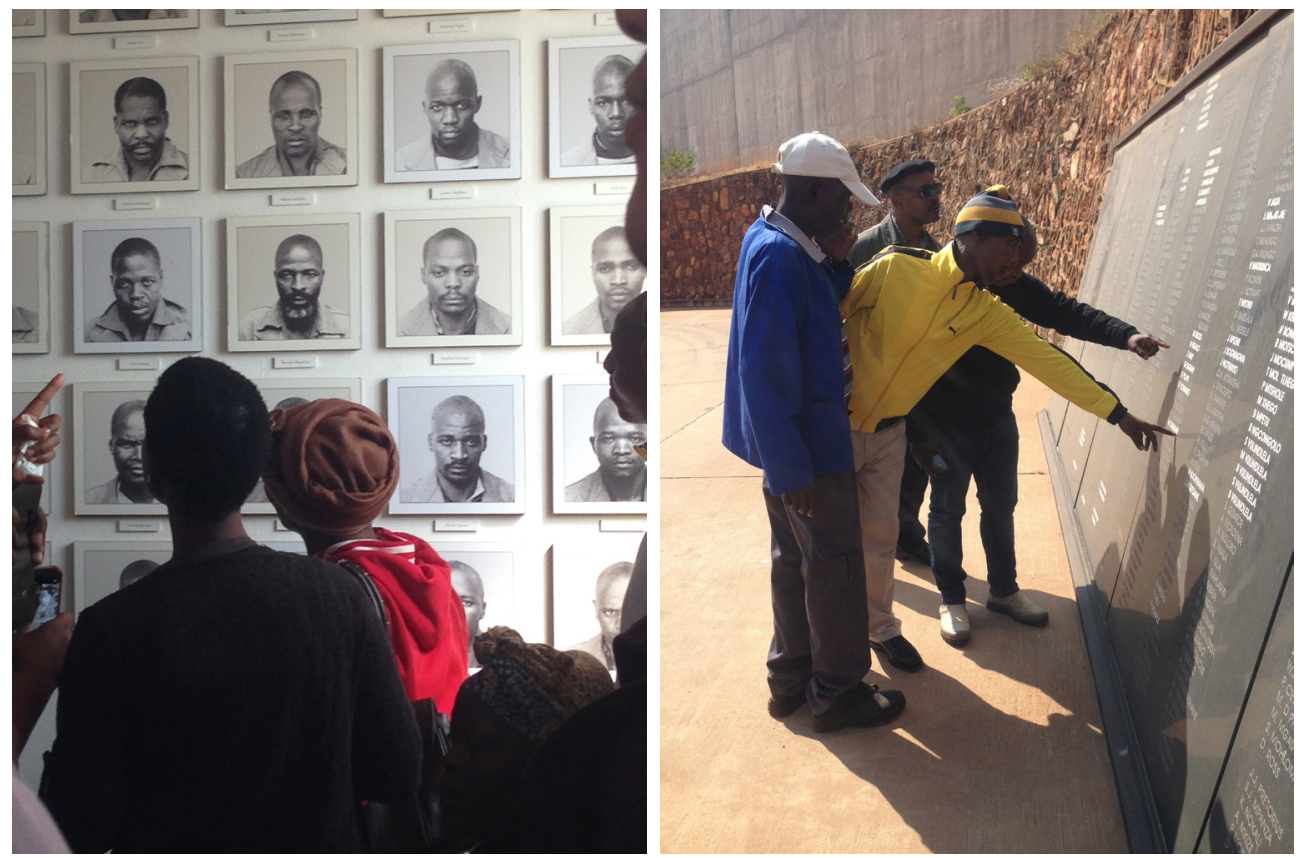

Figure 8 (left): Relatives of some of those hanged for events in Paarl point out the photographs of their relative during a visit to the Gallows Memorial Museum, August 2017. Photograph by Bianca van Laun.

Figure 9 (right): Relatives of some of those hanged for events in Paarl point to the names of their relatives during a visit to the Gallows Memorial Museum, August 2017. Photograph by Bianca van Laun.

exhumations are made visually accessible through the media. ${ }^{54}$ The relatives present often take photographs and video clips of the gravesite and the exhumed remains on their cell phones and distribute these to other family members not present at the site. The MPTT members too, record their findings in photographs taken with digital cameras and cell phones before the bones are removed from the grave. Scholars Francisco Ferrandiz and Alejandro Baer argue that visual records have become an important aspect of exhumations, suggesting that the digital register, instant visual consumption, and extensive distribution, have become an essential part of the process of restitution for victims and relatives who had previously been robbed of memory. ${ }^{55}$ Such images are being added to an international gallery of exhumations that exemplify changing practices associated with the 'unjustly buried. ${ }^{56}$

In preparation for exhumations, and in reconstructing the stories of the deaths, the MPTT, too, has mined and reproduced the same bureaucratic documents and

54 Death Row Prison Manual, accessed at the Department of Correctional Services Museum, Pretoria.

55 F. Ferrandiz and A. Baer, 'Digital Memory: The Visual Recording of Mass Grave Exhumations in Contemporary Spain', Forum: Qualitative Social Research, 9, 3, 2008, http://nbn-resolving.de/urn:nbn:de:0114-fqs0803351; F. Ferrandiz, 'From Tear to Pixel: Political Correctness and Digital Emotions in the Exhumation of Civil War Mass Graves in Spain Today', in E. Delgado, P. Fernandez and J. Labanyi (eds), Engaging the Emotions in Spanish Culture and History (Nashville: Vanderbilt, 2016), 242-261.

Rousseau, 'Identification, Politics, Disciplines', 176. 
photographs from prisoner files that are shown in the museum. The MPTT has done so in ways that extend beyond but also often reproduce their original logic and purpose. The documents are used to help them locate the remains and make an accurate identification. The team relies directly on the identification photographs as well as the physical description of the prisoner provided in the police form (SAP 78) to confirm the race, age, height, dental records, as well as the shape of the occipital bone, the skull, nose, and eye sockets. They also look for notes about significant injuries or scars that might suggest old fractures or affected the bones in some way. ${ }^{57}$ They examine prison death certificates to check that the cause of death is specified as, 'fractured dislocation of the 1st and 2nd cervical vertebrae', and look for these fractures on the remains. This is despite the fact that such fractures are rarely clearly evident from the remains because they have disintegrated. ${ }^{58}$ In such cases, the MPTT has to rely entirely on the presumed accuracy or 'truth' of the prison documents and burial records. ${ }^{59}$

One could then argue that the recovery of the paper remains referring to the hanged prisoners enabled the recovery of their physical remains. The very measurements and details that were required for their identification, subjectification and execution, now aid in the locating, exhumation and rehumanisation of the hanged prisoners. The documents were originally created to fix and confirm the identity of the prisoner. In part, the MPTT's interest in these records is based on the same rationale. However, they put this information to work in ways that the apartheid state could not have foreseen. It seems that the rationale that required that these people be put to death - that is, the political threat they posed to the apartheid state - now operates in reverse. The post-apartheid dispensation requires that they be 'resurrected' both physically and in terms of some of the bureaucratic records generated about them. The reversal of the logic that made it necessary for these people to die in a biopolitical sense in the 1960s now requires them to be brought to life again as 'ancestors of the nation.60

If these photographs and documents were produced through forensic methods, their repurposing by the MPTT could be considered what Allan Sekula terms a practice in counter-forensics. On this notion, Thomas Keenan suggests that Sekula was not referring to the standard professional meaning of counter-forensics (which involves efforts to disrupt or prevent an accurate forensic analysis) but rather raising the question of how the very forensic techniques used by oppressive states can be reversed,

Several of the 1960s' cases have missing fingertips, reflecting a cultural practice whereby people in the Eastern Cape amputated the tip of the fifth phalanx on one hand to identify themselves ethnically as Pondo people.

58 Fullard, unpublished manuscript, 154.

59 Fullard notes that this is particularly so in relation to those who were exhumed in August 2017, many of whom were hanged in the 1960s and buried at Mamelodi cemetery. Their remains were so disintegrated that not even age or sex could be confirmed. In these cases, it was also decided that DNA identification would not be attempted. This decision was based on both 'the reliability of the burial records and the challenges involved in doing DNA identification' - that is, the time required to obtain DNA test results; the difficulty of extracting DNA from the bones due to the degree of deterioration of the remains; the difficulty of finding immediate relatives with whom the DNA samples could be compared, etc. (email correspondence with Madeleine Fullard, 19 February 2018). See also Fullard, unpublished manuscript, 141-159.

Rassool, 'Human Remains', 145. 
such that forensic methods 'become tools of opposition. ${ }^{61}$ In this, Sekula suggests that the 'sequence of actions' works as follows: 'identification-annihilation-identification'. ${ }^{62}$

Indeed, in the case of the judicial executions in South Africa, the taking of identification photographs and the production of a range of documentation relating to prisoners were central to the process of killing them. Today, these same images and documents are being used as evidence. More troubling, perhaps, is the fact that the reinterpretation of this evidence is, as Sekula would suggest, also a matter of 'political maneuvering. While the work is undoubtedly counter-forensic, it is also political in that it consolidates the apartheid state's division of the hanged into separate categories of political versus criminal.

Photographic meaning, as Sekula reminds us, is always relatively indeterminate and the Gallows Memorialisation Project has decided to reframe what the prisoner identification photographs and documents say and do by placing them in new 'presentational circumstances. ${ }^{63}$ Keenan suggests that Sekula's sequence of actions is not entirely symmetrical because the ascribing of names and histories in a post-conflict context differs from how their identities were originally established in order to facilitate their killing. ${ }^{64}$ In fact , the logic that drives the use of state documents and photographs to memorialise particular individuals in the Gallows Museum and by the Exhumation Project, does not entirely disrupt the bureaucratic rationality that produced them; the logic of their current use similarly fixes the identities of particular individuals, albeit to a different end.

During the exhumation process, identity is restored through yet another reproduction of the identification photographs. The photographs are often copied onto sheets of A3-sized white paper, pasted onto cardboard and attached to a stake. Like temporary headstones these are pushed into the ground above the grave. Directly below the image, the individual's name, age, and date of execution are shown. Above the image the phrase, 'in honour of political prisoners executed during the national liberation struggle' again identifies them as political figures. This can be seen as an attempt to restore individual personhood and dignity in the form of even a temporary tombstone bearing the individual's biographical details above graves that were previously unmarked (see Figure 10). ${ }^{65}$ The placards are seemingly produced for the benefit of the families who come to witness the exhumations and view the remains.

The re-presentation of the same prison identification photograph in these multiple guises illustrates how photographs, like documents, can have multiple lives and can be reimagined in myriad ways. Removed from their original contexts, they are incorporated into very different environments to convey an honorific discourse. ${ }^{66}$

61 T. Keenan, 'Counter-Forensics and Photography', Grey Room, 55, 2014, 69; A. Sekula, 'Photography and the Limits of National Identity', Grey Room, 55, 2014, 30.

62 Sekula, 'Limits of National Identity', 30.

63 Sekula, 'Dismantling Modernism', 863.

64 Keenan, 'Counter-Forensics and Photography', 71.

65 See Karl, 'Rehumanizing the Disappeared'.

66 Sekula, 'The Body and the Archive.' 


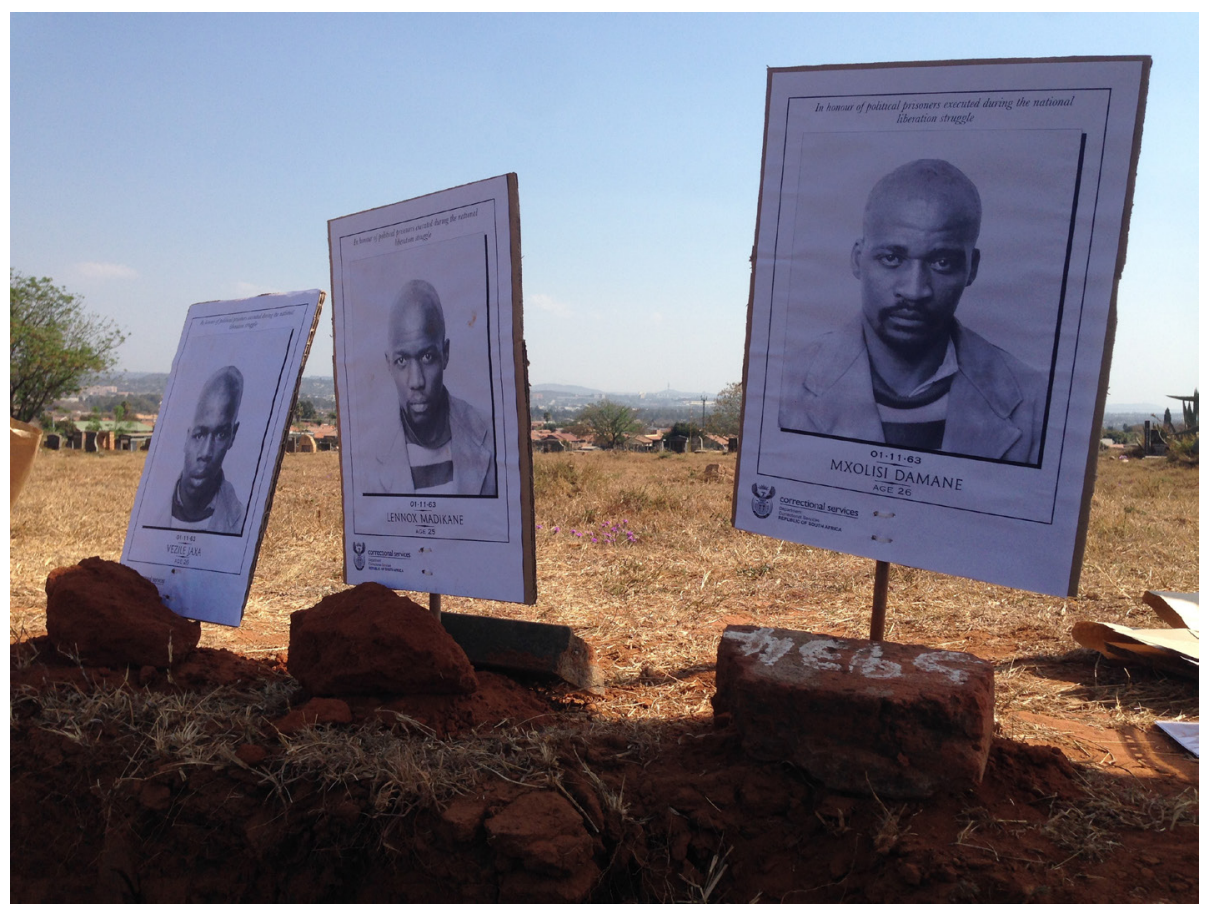

Figure 10: Photographs of three Poqo members above their shared grave, Mamelodi Cemetery, August 2017. Photograph by Bianca van Laun.

With all reference to their production as tools of identification and repression removed, they now appear on posters, in programmes handed out at official handover and reburial ceremonies, and are even attached to the coffins. Many of the photographs have been inserted into new documents that carry the colours and insignia of political organisations. Here, they work to reinsert the hanged political prisoners into an anti-apartheid organisation, as it reclaims 'its' members and heroes who laid down their lives in the struggle and locates them firmly within the discourse of nation-building. No longer standing for an apartheid prisoner, they now represent and honour struggle heroes and martyrs. Ultimately, their identity has been redefined as members of a specific organisation and a particular political biography has been conferred upon them.

However, these new configurations seem to allow very little space for a critical engagement with the bureaucratic systems and ideologies that originally produced the photographs and documents. The documents and photographs are scripted into an honorific role and those writing the new scripts do not seem willing to see how, in seeking to fix the identities of particular individuals, they are perpetuating part of the logic that first oppressed them. This is particularly the case when the images are used at the gravesites to identify certain graves as belonging to particular individuals, or when they are displayed on coffins at handover ceremonies where they continue in some senses to identify the person with the apartheid prisoners portrayed in the photographs (see Figures 11, 12 and 13). 

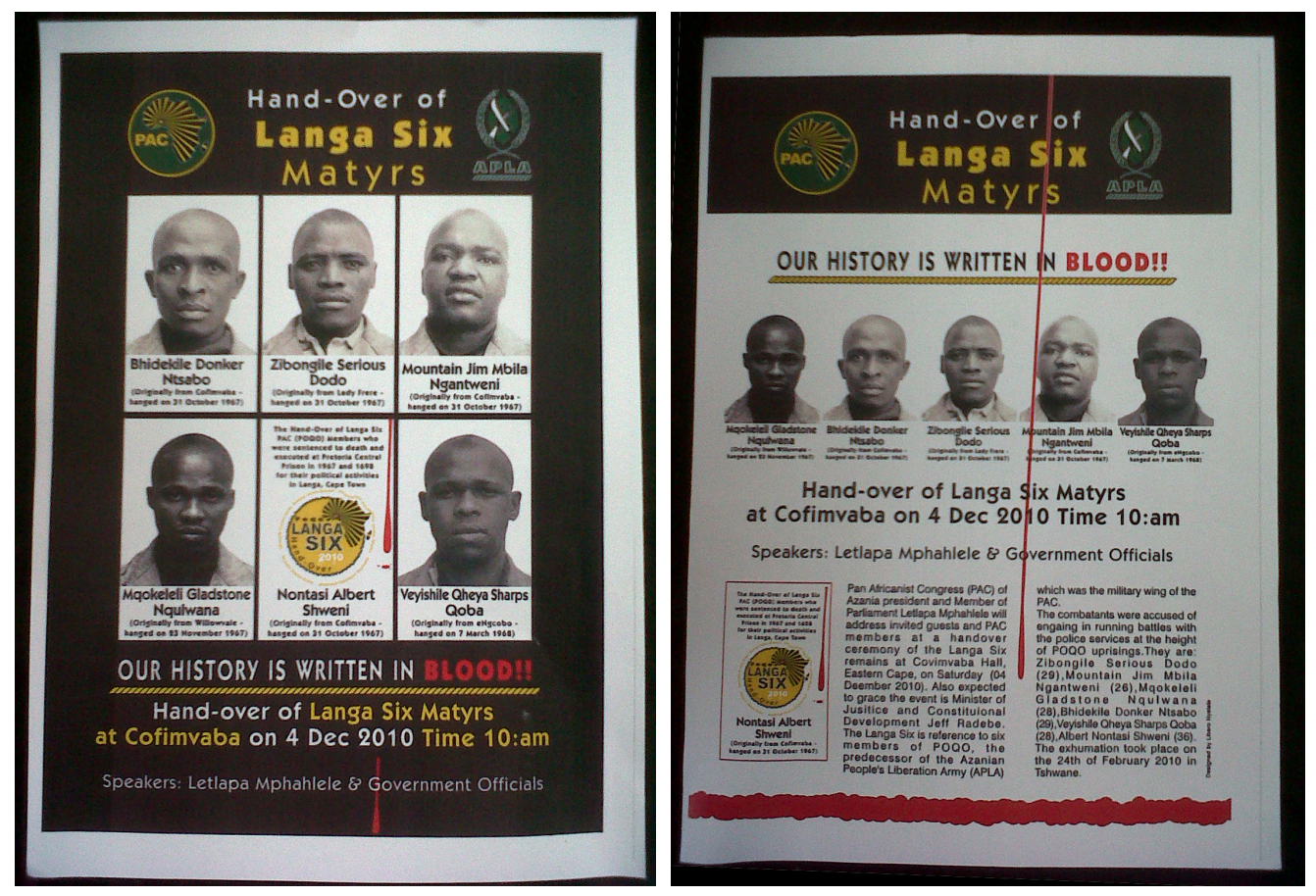

Figure 11: Programme for the official hand-over of the remains of the Langa Six, December 2010. Photograph by Madeleine Fullard.

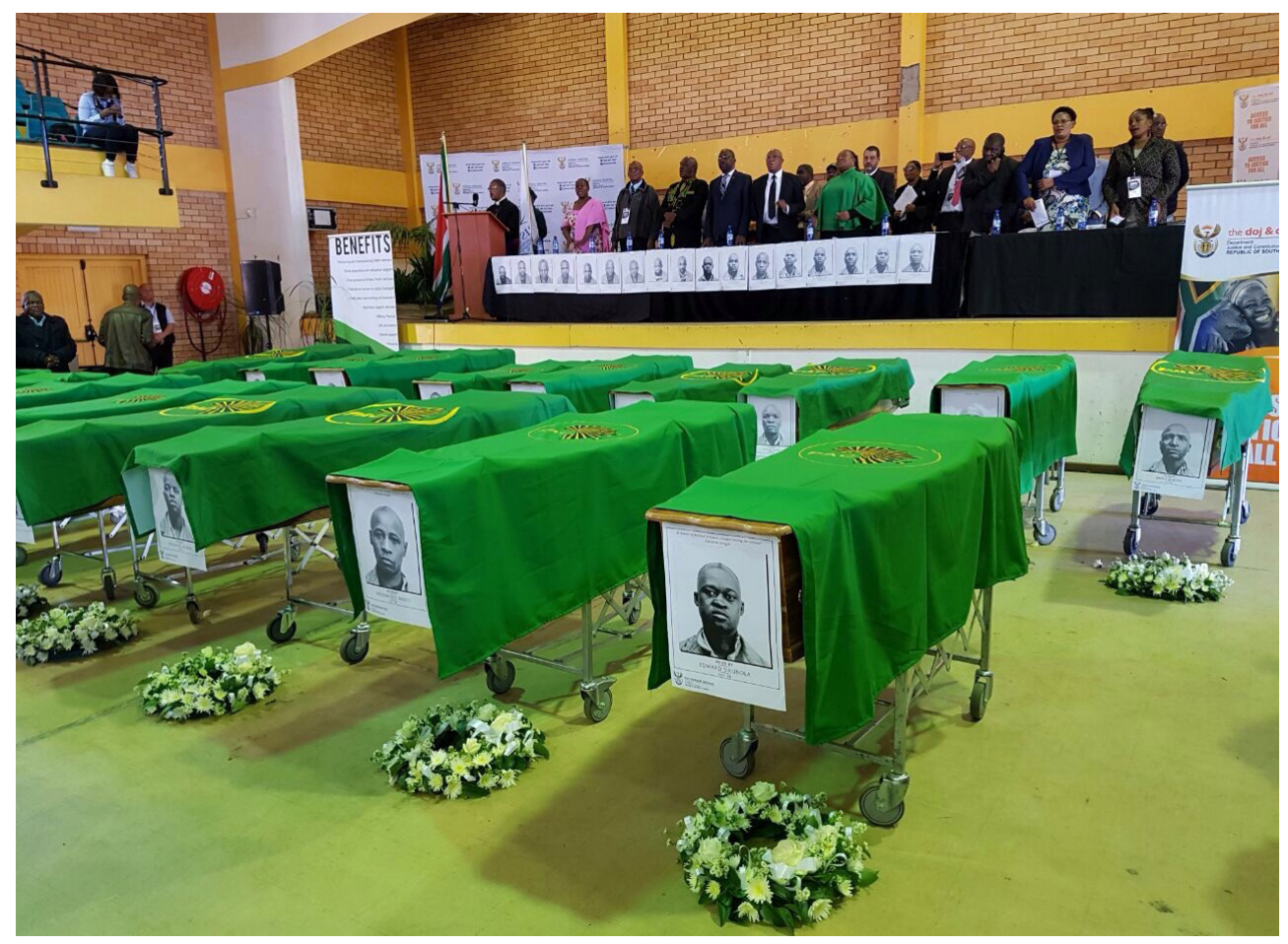

Figure 12: Official ceremony for the handover of the remains of 17 Poqo members, Queenstown, 23 March 2018. Photograph by Madeleine Fullard. 


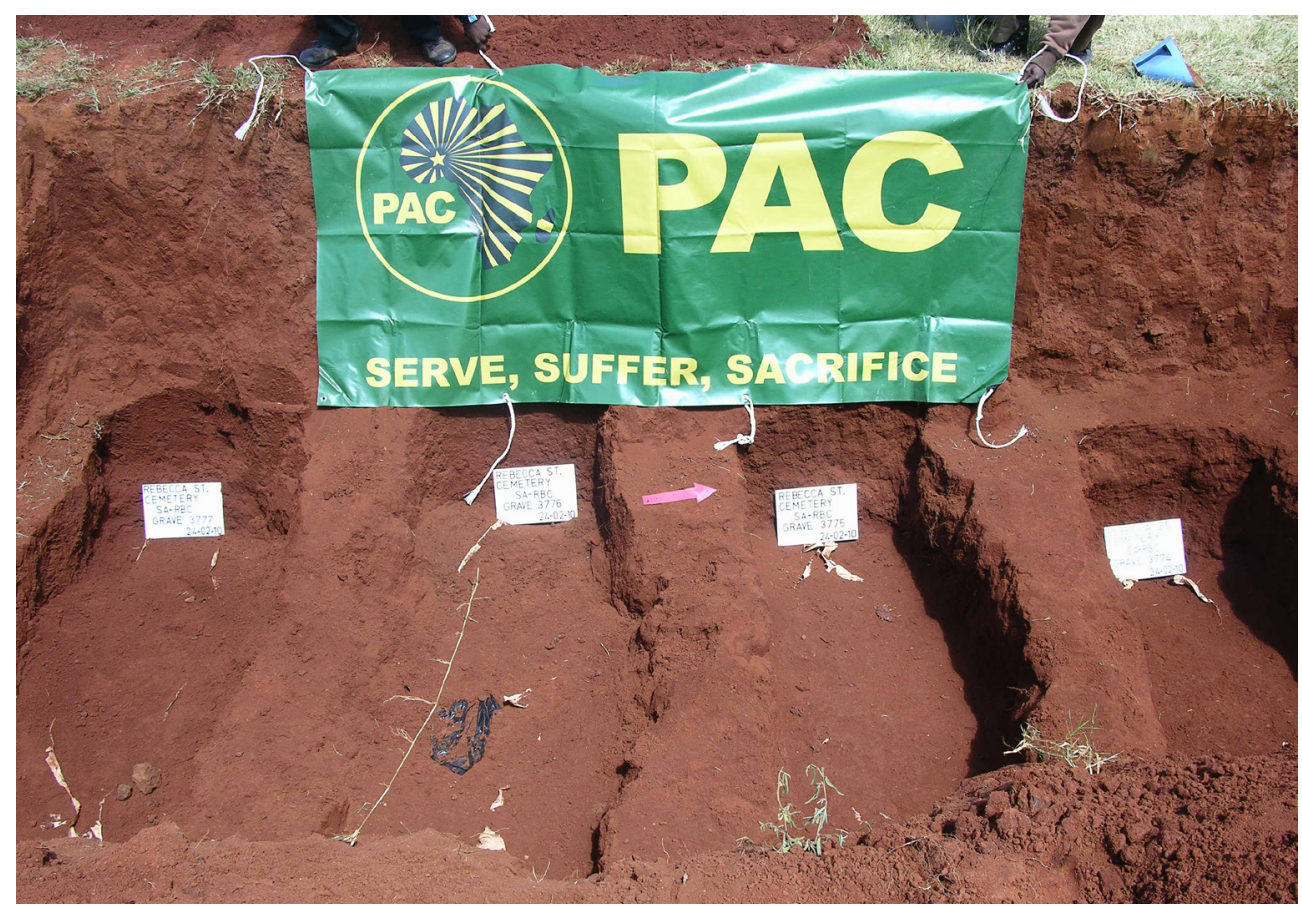

Figure 13: PAC banner over excavated graves in Pretoria, February 2010. Photograph by Madeleine Fullard.

What is restored to these individuals, then, is not so much a personal narrative, but a political biography and affiliation. In death, the men involved in Poqo-led violence during the 1960s are reclaimed by their families, but also by the current state and by PAC factions, as politically driven soldiers and heroes. ${ }^{67}$

As Nicky Rousseau argues in relation to other post-apartheid exhumations and reburials, the emphasis placed on families' opportunity to mourn and heal is overwritten by the inscription of these bodies into what Ciraj Rassool calls a narrative of 'ancestral heroes of the nation.' ${ }^{68}$ This is an example of what Katherine Verdery refers to as the 'political lives of dead bodies', as she explains how certain dead bodies come to animate particular kinds of politics. ${ }^{69}$ In this case, their political biographies allow for the remains of particular individuals to be exhumed and returned to their families. As Edkins suggests, individuals are seen to count not on the basis of who but what they were; the concern with individuals' political biography rather than their full life story creates a politics that misses the person. ${ }^{70}$ Indeed, this can be seen as yet

67 In fact, during the 1960s, Poqo's activities attracted significant criticism within the PAC, which both claimed and denied responsibility for Poqo operations at different times. Maaba, 'The PAC's War', 285; T. ka Plaatjie, 'The PAC's Internal Underground Activities', in South African Democracy Education Trust, The Road to Democracy in South Africa: Volume 2 (1970-1980) (Pretoria: Zebra Press, 2004), 670, 680; K. Kondlo, In the Twilight of the Revolution: The Pan Africanist Congress of South Africa 1959-1994 (Basel: Basler Afrika Bibliographien, 2009), 235; B. van Laun, 'In the Shadows of the Archive: Investigating the Paarl March of November 22nd 1962', (M.A. dissertation, University of the Western Cape, 2012), 69-71.

Rousseau, 'Identification, Politics, Disciplines', 175-202; Rassool, 'Human Remains', 145.

69 K. Verdery, The Political Lives of Dead Bodies: Reburial and Postsocialist Change (Columbia: Columbia University Press, 2000).

Edkins, Missing, 9. 
another form of subjectification of the individual even as it is the political subject that is recovered. No longer fixed only as a prisoner, the same identity is made subject to the agendas of particular political organisations and its power.

\section{Conclusion}

Just as Weld shows in the Guatemalan case, the Gallows Memorialisation Project initiated the 'resurrection' of both the literal bones (or what remains thereof) of the hanged and of their 'paper cadavers' in the form of the archival documents and photographs produced by the apartheid state that have now been reimagined and represented in various attempts at figuring the postapartheid. Following Sekula and Keenan, I suggest that the recovery of bureaucratic records and photographs from the state archives, as well as their reinterpretation and placement in different and new 'presentational circumstances', involved counter-forensic practices and the desire to overturn the oppressive logic inherent in their initial production. The intention was to refigure repressive state documents and photographs as honorific. However, because the documents and photographs are used to fix the identities of particular individuals that the project seeks to honour, the logic behind their representation in new configurations and contexts seems, in some ways, to replicate the bureaucratic rationality that first produced them. There seems to have been a failure to recognise that the logic of the documents and photographs' production continues to constrain the logic of their reinterpretation. In this sense, as Sekula suggests, the symmetry of 'identification-annihilation-identification' comes into play.

However, the documents and photographs are reimagined within the logic of memorialising and rehumanising those put to death by apartheid's political executions rather than in the context of a critique of the bureaucracy of death involved in the apartheid state's wider execution policies. This leaves viewers with little space in which to engage with the conditions in which these documents and photographs were initially created or the bureaucratic rationalities that they reflect. Although the recovery of these documents and photographs is significant in their contribution to identifying the prisoners' remains and revealing the history of capital punishment under apartheid, what is recovered is the bureaucratic state subject and not the individual person. The prisoners are referenced in the records and some biographical information is provided, yet the individual remains missing amidst the bureaucratic record. The official documents and photographs can never provide a basis for recovering the biographical subject; the files and the archives in which they remain continue to be sites of power rather than retrieval.

The repurposing of the documents and photographs in their various guises also leaves little space for critical thought, aiming rather for closure and commemoration than for a renewed critique of the bureaucracy of death involved in apartheid political executions. In some ways, the documents and photographs, alongside with the description of the processes involved in a judicial execution, work to completely overwhelm visitors' senses. In this context, the records act to illustrate the horror of the death penalty rather than to enable visitors to engage with the apartheid regime 
and the kind of state bureaucracy that created these specific records. Ultimately, a tour of the Gallows Museum evokes the horror of the killings by making the visitor to experience the event of killing. However, were the wider memorialisation project to more fully comprehend and expose the bureaucracy of the death penalty during apartheid, its counter-forensic recovery practices might extend a sense of justice and honour to the stories of more of the people who were hanged by the apartheid regime. 